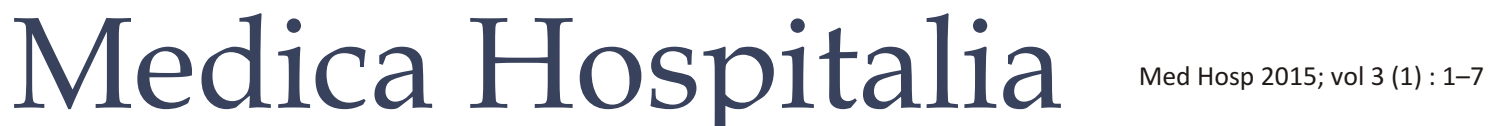

Review Article

\section{Pemberian Antibiotika Rasional pada Infeksi Mata}

\author{
Winarto \\ Bagian Mikrobiologi Fakultas Kedokteran UNDIP dan Bagian/SMF IImu Kesehatan Mata \\ Fakultas Kedokteran UNDIP/Rumah Sakit Dr. Kariadi Semarang
}

\begin{abstract}
Abstrak
Infeksi mata dapat mengenai bola mata dan bangunan yang melapisinya, bangunan adnexa, kulit dan jaringan lunak sekitar mata. Secara klinis infeksi mata mempunyai spektrum klinik dari infeksi ringan sampai keadaan gawat darurat dan dari infeksi yang tidak berpengaruh kepada tajam penglihatan sampai yang menyebabkan kebutaan.

Pengobatan infeksi yang memegang peranan penting ialah pemberian antibiotika, yang mempunyai sifat bakterisidal maupun bateriostatik, dimana obat terakhir ini memerlukan sistim imun yang baik untuk membasmi kuman penyebab.Pemilihan obat secara rasional meliputi tepat indikasi, tepat obat, tepat dosis, tepat lama pemberian dan harganya murah. Salah satu caranya ialah dengan mengikuti prinsip dasar manajemen infeksi yang meliputi pemeriksaan kuman penyebab, tes kepekaan terhadap antibiotika dan pemilihan obat yang sensitif dengan berdasarkan farmakokinetik dan farmakodinamik obat. Data kuman penyebab infeksi dan pola kepekaaan terhadap antibiotika harus dikomunikasikan kepada klinisi, karena digunakan sebagai dasar pengobatan empirik sebelum hasil pemeriksaan untuk obat definitif keluar. Pemberian secara topikal paling banyak digunakan dan dengan cara ini konsentrasi obat yang tinggi di jaringan mata dapat dicapai.

Keratitis yang dapat berlanjut menjadi ulkus kornea dan endoftalmitis adalah contoh penyakit infeksi mata yang dapat menyebabkan kebutaan, dimana di kedua tempat tersebut tidak dapat dijangkau sistim imunitas dengan baik sehingga dianjurkan pemilihan obat bakterisid dari pada bakteriostatik. Sifat obat yang dapat menyebabkan perlukaan epitel kornea dan bersifat toksik terhadap retina juga harus dipertimbangkan. Pemakaian antibiotika secara rasional saja belumlah cukup mengingat munculnya resistensi kuman terhadap antibiotika sehingga yang paling baik ialah penggunaan antibiotika secara bijak (prudent use).
\end{abstract}

\section{Rational antibiotic for eye infection}

\begin{abstract}
Eye and adnexal infection has clinical range from mild infection without visual acuity disturbances up to severe infection in which an emergency cases could end with blindness. Antibiotics has a central role in treatment of eye infections, therefore should be given rationally. Rational of basic principles of infection management consist of identification of causing microbes, sensitivity test to antibiotics and choosing a prompt antibiotics based on pharmacokinetics and pharmacodynamics given to the patient at the right dose, right route, appropiate time and affordable by the patients.

Previous data concerning etiologic agent and pattern of sensitivity to antibiotics were considered when give an empiric treatment, therefore theese data should be published to clinicians regularly. The part of the eye which diffcult to be reached by immune system, it is advisable to choose a bactericidal antibiotics rather than bacteriostatic, e.g. keratitis, corneal ulcer and endophthalmitis. Toxic effects to the corneal epithelium and retinal cell should be bear in mind in order to treat eye infections to obtain best results.
\end{abstract}




\section{PENDAHULUAN}

Pengobatan antibiotika rasional, ialah antibiotik yang dibutuhkan sesuai dengan kebutuhan klinik, sesuai dengan dosis yang dibutuhkan berdasar kasus masingmasing untuk periode waktu yang cukup dan dengan harga yang paling murah. ${ }^{1}$ Dengan kata lain sesuai indikasi, sesuai dosis, cukup waktu pemberian dan termurah. Pada kesempatan ini mungkin penulis tidak dapat memenuhi sesuai dengan judul yang dimintakan oleh redaksi karena adanya berbagai keterbatasan. Sesuai indikasi, seperti diketahui bahwa infeksi mata secara klinis mempunyai rentang klinis lebar, yang sangat bervariasi dari infeksi yang tidak termasuk kegawatan sampai yang masuk kegawatan mata, dari infeksi yang mengancam kebutaan sampai infeksi yang tidak mempengaruhi tajam penglihatan. Sesuai dosis dan lama pemberian, pemberian antibiotika pada infeksi mata diberikan secara topikal, injeksi subkonjungtiva, injeksi intra vitreal dan parenteral yang mempuyai dosis dan lama pemberian berbeda beda tergantung dari kasusnya, tetapi secara farmakokinetik diharapkan akan mencapai tempat infeksi dengan konsentrasi cukup. Termurah, ini merupakan hal yang cukup sulit dipertimbangkan karena tidak hanya menyangkut harga tetapi menurut kami harus dipertimbangkan juga tentang nilai (value). Harga obat murah yang efektifitasnya diragukan akan menjadi sangat mahal bila dibandingkan dengan obat paten yang harganya relatif lebih mahal tetapi efektifitasnya sangat nyata. Walaupun demikian, kami akan mencoba menguraikan berbagai hal yang berkaitan dengan infeksi mata dan pengobatan antibiotika, sehingga dapat menggambarkan tentang rasionalitas penggunaan antibiotika.

\section{Mikrobiologi Mata dan Infeksi Mata}

Permukaan kulit kelopak mata, kornea dan konjungtiva merupakan bagian terluar mata yang mempunyai flora normal, mempunyai risiko terbesar untuk terjadinya infeksi oleh kuman patogen ataupun kuman oportunistik lewat berbagai rute. Dalam keadaan normal epithel mata sukar ditembus oleh kuman. Air mata yang secara kontinyu diproduksi dibantu dengan releks mengedip, maka secara mekanik akan membasuh permukaan kornea dan mencegah penimbunan kuman. Permukaan bola mata dilapisi lapisan air mata yang mengandung zat antimikroba, misalnya lysozym dan beta-lysin serta imunogloblin sehingga kejadian kotaminasi di konjungtiva fornix sangat kecil. Lysozym dapat merusak dinding kuman terutama kuman gram $(+)$, kadarnya menurun seiring dengan penuaan dan sangat berkurang pada sindroma mata kering. Beta-lysin bekerja terutama pada membran sel bersama dengan lysozym, tetapi juga berada di lapisan air mata ${ }^{2-4}$

Diantara kuman gram positif, Staphylococcus merupakan kuman tersering sebagai flora normal di kulit dan konjungtiva tetapi dapat juga menyebabkan infeksi follikel cilia (hordeolum), blefaritis akut dan blefaritis kronis, infeksi aparatus lakrimal, konjungtivitis akut, keratitis dan setelah terjadinya septikemia dapat menyebabkan endoftalmitis. Neisseria dan kuman gram negatif lainnya dapat sebagai flora normal konjungtiva atau saluran nafas atas tetapi menyebabkan ophthalmia neonatorum. Candida albicans bisa didapatkan di konjungtiva, mempunyai potensi menyebabkan ulkus kornea, konjungtivitis dan uveitis. Aspergilus banyak ditemukan di lingkungan/tumbuhan dan menyebabkan keratomikosis (infeksi kornea oleh jamur). Sedangkan kelompok virus yang penting dimata ialah herpes zoster, herpes simplex tipe 1 dan cytomegalovirus. ${ }^{2,5}$

Infeksi pada mata dapat berupa infeksi dengan spektrum yang luas, mengenai jaringan mata mulai dari bagian depan bola mata (anterior segment), bagian belakang bola mata (posterior segment) sampai ke adnexa dan jaringan sekitar. Misalnya blefaritis, hordeolum externum, hordeolum internum, konjungtivitis, keratitis yang dapat melanjut menjadi ulkus kornea, skleritis, dakrioadenitis, kanalikulitis, dakriosistitis, selulitis preseptal, dan selulitis orbita. Sedangkan infeksi pada segmen belakang bola mata berupa endoftalmitis dan panoftalmitis, yang tidak hanya meningkatkan morbiditas penyakit mata tetapi yang lebih parah lagi ialah menyebabkan kebutaan. ${ }^{6}$

Infeksi bagian belakang bola mata dapat terjadi melalui salah satu cara berikut, yaitu (1) sebagai akibat operasi intra okuler, (2) setelah trauma penetrans bola mata, (3) perluasan lanjut (extention) dari keratitis atau ulkus kornea, serta (4) penyebaran hematogen dari infeksi yang berasal dari tempat yang jauh. Keratitis bakterial merupakan salah satu infeksi yang mengancam kebutaan, kuman Pseudomonas aeruginosa dan Staphylococcus aureus merupakan kuman yang dapat merusak epithel dan stroma kornea secara progresifsehingga menyebabkan perforasi kornea atau melanjut menjadi endoftalmitis. .,7 $^{2}$

Pengobatan yang berhasil baik, memerlukan pemberian antibiotika sedemikian rupa sehingga konsentrasi antibiotika yang tinggi dapat dicapai di jaringan mata yang terinfeksi dalam waktu yang cukup agar efek antibakterialnya nyata dan efektif. Kendala awal yang dihadapi adalah ketidak tahuan tentang jenis kuman penyebab infeksi, karenanya antibiotika yang seharusnya diberikan juga tidak diketahui. Kalau menunggu hasil pemeriksaan kultur kuman dan tes sensitifitas terhadap antibiotika, yang memerlukan waktu antara 3-5 hari;maka keadaan klinis pasien akan menjadi lebih jelek. Oleh karena itu pilihan awal adalah pemilihan antibiotika secara empiris, yaitu pemilihan antibiotika berdasarkan gambaran pola kuman dan pola kepekaannya terhadap antibiotika yang telah dilaporkan sebelumnya. Pemeriksaan mikrobiologi untuk 
menentukan kuman penyebab infeksi dan pola kepekaann terhadap antibiotika harus dilakukan karena data-data ini akan dipakai sebagai dasar pemilihan obat antibiotika empiris. Sampel harus diambil dari tempat infeksi dan tidak boleh terkontaminasi dengan jaringan sekitarnya, diambil sebelum diberikan antibiotika. Hasil pemeirksaan Mikrobiologi klinik tidakhanya berguna buat pemilihan obat definitif bagi pasien sendiri tetapi secara berkala harus dianalisa dan disajikan agar klinisitahu dandapat menggunakan sebagai dasar pengobatan empiris. ${ }^{6}$

Pengobatan antibiotika yang memadai padainfeksi mata memerlukan pengertian tentang proses penyakit,pengetahuan farmakologi dan farmakokinetik obat yang digunakan. Pemakaian antibiotika yang tepat sangat penting untuk mempertahankan visus pada infeksi mata yang berat seperti keratitis bakterial dan endoftalmitis. ${ }^{8}$

\section{Prinsip Umum Pemakaian Antibiotika}

Antibiotika yang mampu membunuh kuman mempunyai sifat bakterisidal, sedangkan yang menghambat pertumbuhan kuman bersifat bakteriostatik. Pemakaian obat bakteriostatik memerlukan bantuan sistim imun untuk eradikasi dan pembersihan kuman. Keratitis dan endoftalmitis adalah infeksi di jaringan yang avaskuler, dimana di kedua tempat ini sistim imun tidak cukup kuat untuk mengontrol infeksi kuman guna mencegah sequelle yang menyebabkan kebutaan. Dalam waktu 24 jam kuman berkembang biak dan menghasilkan toksin dan enzimenzim perusak sehingga menghancurkan fungsi dan jaringan mata. Dalam keadaan demikian, apalagi dalam keadan infeksi berat; maka antibiotika yang bersifat bakterisidal lebih disenangi. Yang termasuk antibiotika bakterisidal ialah penicilin, cefalosporin, aminoglikosida dan fluoroquinolone, sedangkan yang bersifat baktriostatik ialah tetrasiklin, eritromisin, khloramfenikol dan sulfonamide yang digunakan untuk mengobati infeksi yang ringan atau memang mempunyai efek khusus, misalnya tetrasiklin untuk rosasea mata, sebagai anti kolagenase pada ulkus kornea atau untuk mengencerkan sekret kelenjar meibom. ${ }^{8,9}$

Pemberian antibiotik secara topikal pada umumnya mampu mengantarkan antibiotika pada tempat infeksi dengan konsentrasi tinggi. Antibiotika topikal harus dapat menembus epithel kornea yaitu suatu membran permeabel selektif; yang dilapisi oleh lapisan air mata (tear film), kemudian melewati beberapa struktur segmen depan bola mata (yaitu lensa dan zonula Zinnii) dan uvea anterior sebelum masuk ke dalam vitreus. ${ }^{10}$ Pada konjungtivitis dan keratitis, antibiotika langsung diteteskan pada tempat infeksi, tetapi pada endoftalmitis antibiotika harus melalui kornea dan humor aquos sehingga konsentrasi teurapeutik antibiotika tidak akan tercapai.

Berbagai faktor yang mempengaruhi penetrasi intraokuler obat ialah muatan (charge) obat, status epitel kornea, derajat peradangan, formulasi obat, konsentrasi obat dan dosis obat. Sifat kimiawi obat mempengaruhi penetrasi obat, dalam arti kemampuannya menembus kornea. Lapisan luar epitel kornea kaya lipid sedangkan bagian dalam stroma banyak mengandung air sehingga diperlukan obat yang mempunyai sifat bifasik sehingga mampu menembus epithel dan stroma kornea. Sifat $\mathrm{pH}$, sistim buffer dan besar molekul sangat mempengaruh penetrasi obat. Pada umumnya obat antibiotik untuk mata menggunakan obat dengan molekul kecil sehingga mudah menembus membran biologi, tetapi basitrasin, kolistin dan polymixin adalah obat dengan molekul besar sehingga penetrasi ke kornea jelek, karenanya baik digunakan untuk infeksi superfisial. ${ }^{8}$

Beberapa obat dapat menyebabkan kerusakan kecil pada epitel dan sifat microtoxicity ini dapat meningkatkan penetrasi obat. Hal ini bisa terjadi bila menggunakan pengawet ethylenediaminetetra-acetate (EDTA) atau sodium benzoate. Peradangan mata juga dapat menyebabkan kerusakan epitel kornea dan meningkatkan penetrasi obat. Turn over lapisan air mata relatif cepat sehingga formula yang mempertahankan keberadaan obat di lapisan air mata akan meningkatkan konsentrasi obat. Hal ini dapat dicapai dengan membuat obat lebih kental (viscous) atau dalambentuk salep karena mempunyai contact time lebih lama. Obat hidrofilik mungkin akan mengkristal di dalam salep sehingga menghambat pelepasan dan penetrasinya, akibatnya menurunkan bioavailability obat. ${ }^{8}$

Peninggian konsentrasi antibiotika akan meningkatkan difusi dan penetrasi kornea. Antibiotika "fortified" memberikan konsentrasi yang lebih tinggi di kornea dan humor aquos. Ciprofloxacin 0,3\% dan ofloxacin $0,3 \%$ menunjukkan konsentrasi teurapeutik yang cukup di kornea. Teknik pemberian dosis tertentu dapat digunakan untuk meningkatkan keunggulan pemakaian obat topikal pada infeksi berat. Pemberian obat 1 tetes setiap menit selama 5 menit, yang kemudian diulang setelah 1jam mampu meningkatkan konsentrasi obat di kornea sampai >100 $\mu \mathrm{g} /$ gram jaringan kornea. Gentamisin sulfat 0,3\% yang diberikan 1 tetes setiap 30-60 menit secara menetap, akan memberikan efek optimal. Apabila pemberiannya lebih dari 1 macam antibiotika, maka perlu diberikan waktu jeda antara paling tidak 5 menit diantara obat satu dengan obat lainnya, untuk menghindari terjadinya "washout" 8,9

Toksisitas obat topikal dapat disebabkan oleh obat antimikroba, bahan pengawet atau bahan pembawa obat. Antibiotika dapat menghambat penyembuhan epitel kornea dan lebih nyata pada pemakaian obat fortified. Oleh karena itu pemakaian obat fortified hanya digunakan pada awal saja sebagai loading dose, yang tidak lebih dari 3 hari. Bahan pengawet thimerosal dan mercuri 
dapat menyebabkan reaksi hipersensitifitas, keratokonjungtivitis dengan permukaan kornea kasar, giant papillary conjungtivitis, infiltrat di stroma kornea dan band keratopathy. Benzalkonium chloride dapat menghambat adhesi epitel, hilangnya epitel superfisial dan memperlambat penyembuhan epitel. Efek samping beserta efek melapisi permukaan (surfactant) dari benzalkonium dapat meningkatkan penetrasi antibiotika. $^{8,9}$

\section{Cara Pemberian Antibiotika}

Prognosis endoftalmitis jelek meskipun sudah diberikan antibiotika progresif secara topikal, parenteral dan periorbital karena tidak dicapai konsentrasi antibiotika yang cukup. Oleh karena itu diperlukan pemberian antibiotika secara intra vitreal untuk mencapi kadar antibiotika yang cukup dalam waktu relatif lama, hanya saja sifat toksik ke retina yang menjadi masalah. Contohnya dosis gentamisin 100-400 pug, cefazolin atau methicillin $2 \mathrm{mg}$, amikasin $400 \mathrm{ug}$ dan vancomycin $1 \mathrm{mg}$. Karena dekatnya rentang dosis toksik dan dosis teurapeutik dari aminoglikosida, maka obat ini harus diinjeksikan di bagian depan atau tengah vitreus untuk mencegah dosis berlebihan di dekat retina. ${ }^{10}$

Antibiotika parenteral diindikasikan untuk selulitis preseptal, selulitis orbita, dacryosistitis dan sebagai tambahan pada pengobatan endoftalmitis atau keratitis yang meluas ke sklera, ancaman ruptur kornea atau sudah terjadi ruptur kornea. Selain itu, konjungtivitis gonorrhoeae pada usia berapapun, Pseudomonas, Haemophilus dan Chlamydia pada neonatus seharusnya diobati dengan antibiotika parenteral. ${ }^{8}$

Antibiotika topikal efektif dan aman digunakan sebagai profilaksis edoftalmitis post operatif dan trauma penetrans. Antibiotika topikal baik diberikan 24 jam sebelum operasi intra okuler untuk menurunkan jumlah kuman di fornix konjungtiva. Injeksi antibiotika subkonjungtiva juga efektif untuk mencegah endoftalmitis post operatif, tetapi karena efek samping pemakaian aminoglikosida yaitu perdarahan dan efek toksik, maka cefalosporin lebih disenangi. Sekarang injeksi subkonjungtiva post operatif ini sudah ditinggalkan dan diganti dengan obat topikal golongan quinolone yang mempunyai efektifitas yang sama dan efek samping sangat minimal, misalnya gatifloxacin $0,3 \%$ atau moxifloxacin $0,5 \%{ }^{11}$

Infeksi yang berat seperti keratitis bakterial, endoftalmitis atau selulitis orbita jelas memerlukan pengobatan antibiotika yang progressif dengan antibiotika spektrum lebar. Pada sebagian besar kasus, macam kuman penyebab infeksi belum diketahui. Oleh karena itu spesimen harus diambil sebelum diberi antibiotika agar kuman dapat diisolasi dan pengobatan yang tepat tidak terlambat. Untuk mengatasi masalah ini, pada ulkus kornea diberikan pengobatan empiris dengan combined fortified antibiotics sampai hari ke tiga, yang kemudian diteruskan dengan pengobatan definitif, sesuai hasil kultur dan kepekaan terhadap antibiotika dari laboratorium mikrobiologi klinik. ${ }^{9}$

Resistensi kuman terhadap antibiotika merupakan hal serius yang perlu mendapatkan perhatian dari para dokter, yang terjadi hampir terhadap semua jenis antibiotika mata. ${ }^{12}$ Resistensi terhadap antibiotika muncul apabila digunakan antibiotika dalam jangka lama sehingga strain kuman yang sensitif mati tetapi strain yang resisten yang semula hanya sedikit jumlahnya, dapat memperbanyak diri sehingga menjadi dominan. Pengobatan infeksi akut dan profilaksis yang biasanya diberikan dalam waktu pendek, mungkin kecil pengaruhnya terhadap terjadinya resistensi kuman. Informasi tentang pola kuman dan pola resistensi terhadap antibiotika sangat perlu sebagai dasar pengobatan empirik, khususnya pada kasus infeksi berat yang mempunyai potensi menyebakan kebutaan, misalnya keratitis bakterial atau ulkus kornea.

Mengingat spektrum penyakit infeksi mata yang luas, rasanya tidak memungkinkan dibahas semuanya dalam tulisan ini. Sebagai contoh untuk pembahasan lebih lanjut pada kesempatan ini ialah keratitis bakterial dan endoftalmitis, penyakit yang mempunyai potensi menyebabkan kebutaan.

\section{Keratitis Bakterial}

Keratitis bakterial adalah infeksi bakteri pada kornea. Sistim pertahanan terhadap infeksi meliputi permukaan epitel kornea yang utuh, gerak mengedip dari kelopak mata, dan bahan kimiawi yang ada di dalam lapisan airmata yang mempunyai efek antibakterial, seperti lizozym, beta-lysins dan immunoglobulin A. Infeksi terjadi apabila sistim pertahanan lini pertama tersebut mengalami gangguan, terjadi defek epitel, kuman patogen masuk ke jaringan kornea kemudian memperbanyak diri dan terjadilah kolopnisasi yang melanjut menjadi keratitis. Prosesnya akan berlanjut dan terbentuk jaringan nekrotik dimana jaringan nekrotik ini lepas kemudian terbentuk ulkuskornea, apabila sembuh terbentuk sikatrik kornea yang akan berpengaruh terhadap ketajaman penglihatan. ${ }^{8}$

Pemeriksaan sederhana tetapi rasional ialah dengan pengecatan Gram dari spesimen ulkus kornea sehingga dapat diketahui apakah kumannya termasuk kuman gram (+) atau kuman gram (-), sehingga obat antibiotika empirik yang diberikan disesuaikan dengan hasil pengecatan. ${ }^{8,10,11}$ Seringkali karena jenis kuman penyebab tidak segera dapat diketahui, untuk mengatasi infeksi yang berat tersebut dipilih pengobatan empirik menggunakan kombinasi dua antibiotika, dengan istilah "shotgun" approach, yaitu dimulai dengan pemberian kombinasi sefalosporin dan aminoglikosida dosis tinggi (fortified) agar di jaringan kornea didapatkan kadar antibiotika dengan konsentrasi tinggi sebelum efek 
toksik kuman timbul sehingga efek bakterisidal yang cepat dapat dicapai. Obat yang dipakai ialah kombinasi tobramycin 2\% dengan cefamandole nafate 5\% atau gentamisin 0,9-1,2 \% dengan cefazolin 5\%. Pengobatan diberikan setiap setengah jam selang-seling sampai 24 jam, kemudian dilakukan tapering bertahap sampai hasil kultur dan tes sensitifitas keluar dan dilanjutkan dengan pengobatan definitif menggunakan obat tunggal yang sesuai. ${ }^{8}$

Alternatif kedua adalah menggunakan obat tungal quinolone generasi baru, misalnya Ciprofloxacin $0,3 \%$, Ofloxacin $0,3 \%$ atau Lomefloxacin 0,3\%. Cara ini sebetulnya memudahkan dokter dan pasien untuk pemberiannya, yang juga akan meningkatkan ketaatan berobat (compliance). Ada kontroversi tentang pemakaian quinolone ini karena ada kuman penyebab keratitis yang tidak sesuai dengan coverage kerja obat, misalnya Streptococcus pneumonia. Ada juga laporan yang menyatakan bahwa pada ulkus kornea yang luas diobati dengan quinoloe ternyata angka perforasinya lebih besar. Karena itu ada yang membedakan berdasarkan luas ulkus kornea, pada ulkus kecil (diameter $<3 \mathrm{~mm}$ ) dapat menggunakan monoterapi, tetapi yang ulkusnya luas (diameter $>3 \mathrm{~mm}$ ) menggunakan antibiotika kombinasi. ${ }^{9}$

Pengobatan subkonjungtiva atau intravena biasanya diberikan pada kasus ancaman perforasi ulkus (impending perforation) atau kalau infeksinya meluas ke sklera. Injeksi subkonjungtva memberikan rasa nyeri hebat pada pasien dan menyebabkan sikatrik konjungtiva tetapi konsentrasinya lebih tinggi dibandingkan pemberian topikal yang frekuen walaupun kadarnya tidak lebih dari 5 jam. ${ }^{8}$

Pemakaian collagen shields (lensa kontak yang dibuat dari kolagen binatang dan dicelupkan ke larutan antibiotika) mungkin memberikan kadar antibiotika yang tinggi di kornea tetapi lensa kontak akan mencegah sistim pembersihan dari gerak palpebra dan lapisan air mata serta menyebabkan timbunan toksin dan ensim kuman di tempat infeksi.

Sudah barang tentu pengobatan pasien ulkus kornea tidak hanya cukup dengan pemberian antibiotika saja tetapi juga obat yang lain, misalnya siklopegi sulfas atropin, anti inflamasi non steroid, antioksidan dan anti collagenase, yaitu oxytetrasiklin salep mata. Pemberian steroid masih terjadi kontroversi ada yang tidak setuju dan ada yang setuju, yaitu diberikan beberapa hari pada awal saja bersamaan dengan pemberian antibiotika. Serum otolog mengandung banyak faktor pertumbuhan jaringan (growth factors) sehingga penambahan serum otolog akan mempercepat epitelisasi kornea. Faktor predisposisi lokal maupun sistemik juga harus dicari dan dikoreksi, misalnya blefaritis, disfungsi kelenjar meibom, dacryocystitis, diabetes mellitus. ${ }^{9}$

\section{Endophthalmitis}

Endoftalmitis merupakan infeksi yang paling merusak dan mengancam tajam penglihatan, termasuk keadaan gawat darurat mata, memerlukan pengobatan antibiotika segera dan agresif. Endoftalmitis terjadi biasanya setelah

\begin{tabular}{|c|c|c|c|}
\hline \multirow{3}{*}{ Cara pemberian } & \multicolumn{2}{|c|}{ Antibiotika awal untuk Endoftalmitis } & \\
\hline & \multirow[t]{2}{*}{ Infeksi Traumatik } & \multicolumn{2}{|c|}{ Infeksi Post operatif } \\
\hline & & $\begin{array}{l}\text { Endophtalmitis } \\
\text { Vitrectomy Study }\end{array}$ & $\begin{array}{c}\text { Bascom Palmer Eye } \\
\text { Institute }\end{array}$ \\
\hline \multirow[t]{3}{*}{ Intravitreal (dalam 0,1 ml) } & Vancomycin $\mathrm{HCl}, 1 \mathrm{mg}$ & Vancomycin $\mathrm{HCl}, 1 \mathrm{mg}$ & Vancomycin $\mathrm{HCl}, 1$ mg \\
\hline & Amikasin sulfat, $0,4 \mathrm{mg}$ & Amikasin sulfat, 0,4 mg & Ceftazidime, 2,25 mg \\
\hline & & & Dexametason 0,4 mg \\
\hline \multirow[t]{3}{*}{ Subconjungtiva (dalam 0,5 ml) } & Vancomycin $\mathrm{HCl}, 25$ mg & Vancomycin HCl, 25 mg & Vancomycin $\mathrm{HCl}, 25$ mg \\
\hline & Gentamisin sulfat, 20 mg & Ceftazidime, $100 \mathrm{mg}$ & Ceftazidime, 25-50 mg \\
\hline & & & Dexametason, $12-24 \mathrm{mg}$ \\
\hline \multirow[t]{3}{*}{ Topikal } & Vancomycin $\mathrm{HCl}, 5 \%$ & Vancomycin $\mathrm{HCl}, 5 \%$ & Vancomycin $\mathrm{HCl}, 5 \%$ \\
\hline & Gentamisin sulfat, $0,24 \%$ & Amikasin sulfat & Ceftazidime, $5 \%$ \\
\hline & & & Corticosteroids \\
\hline \multirow[t]{3}{*}{ Parenteral } & Clindamycin fosfat & Amikasin sulfat & Vancomycin $\mathrm{HCl}$ \\
\hline & Amikasin sulfat & Ceftazidime & Ceftazidime \\
\hline & Ciprofloxacin $\mathrm{HCl}$ & & \\
\hline
\end{tabular}


trauma penetrans atau setelah operasi intra okuler dan lebih jarang lagi terjadi secara hematogen. Basilus lebih sering didapatkan pada trauma penetrans, sedangkan kuman pada endoftalmitis post operatif didapatkan kuman yang biasanya menjadi fora normal tepi kelopak mata seperti S. epidermidis, S. aureus, Streptococcus dan kuman batang gram negatif. Endoftalmitis lambat (late onset endophthalmitis) yang terjadi setelah 3 bulan, disebabkan oleh Propionibacterium acnes. ${ }^{8,10}$

Pengobatan antibiotika paling efektif untuk mempertahankan tajam penglihatan bila diberikan pada tahap awal, yaitu beberapa jam awal saat terdeteksinya gejala dan belum terjadi kerusakan jaringan yang penting. Vitreus yang terinfeksi dibersihkan dengan vitrektomi. Spesimen diambil dari fornix inferior, kemudian dari vitreus dengan cara aspirasi menggunakan jarum (23-gauge needle aspirates) atau pada saat vitrektomi. Antibiotik diberikan secara intra vitreal, kemudian diberikan secara subkonjungtiva, fortified drops dan intra vena. Daftar antibiotika yang digunakan dapat dilihat pada tabel 1 di atas atau berdasarkan sumber pustaka baru lain yang berbasis bukti (evidence based). ${ }^{8}$

\section{SIMPULAN}

Pengelolaan infeksi mata berat yang menyebabkan kebutaan perlu mendapatkan perhatian serius. Tersedianya berbagai macam antibiotika di pasaran, termasuk antibiotika baru; yang dapat digunakan untuk infeksi mata merupakan hal yang menyenangkan karena tersedianya pilihan antibiotika yang beragam. Di pihak lain, dilaporkan juga tentang resistensi kuman terhadap antibiotika maka akan menyulitkan klinisi dalam pemilihan obat tersebut. Sebaiknya kita mengingat kembali tentang manajemem penyakit secara rasional, salah satunya ialah tahapan diagnsosis rasional dari penyakit infeksi, khususnya infeksi mata yang meliputi penegakkan diagnosis klinik, pengambilan spesimen, pemeriksaan kultur dan tes kepekaan terhadap antibiotika. Dengan cara ini diketahui kuman penyebab dan sensitifitas terhadap antibiotika, sehingga antibiotika dipilih secara rasional berdasar bakteri penyebab. Tinggal pilihan cara pemberian yang memungkinkan kadar antibiotika mencapai konsentrasi tinggi di jaringan infeksi. Data-data tersebut secara berkala harus disajikan ke klinisi agar dapat digunakan sebagai dasar pemilihan pengobatan empirik.

Kontroversi muncul kemudian ialah pada pengobatan empirik yaitu pemakaian terapi "shotgun" yang menggunakan antibiotika spektrum luas, yang seharusnya hanya diberikan pada tahap awal sebelum kuman penyebab dapat diidentifikasi. Saat ini semakin banyak obat baru yang mempunyai kemampuan "super" dalam membunuh kuman, baik sebagai obat tunggal ataupun obat kombinasi. Akibatnya terlihat adanya kecenderungan untuk melupakan tahapan rasional dari manajemen penyakit infeksi dan menggunakan jalan pintas memakai antibiotika "super". Harus pula diingat bahwa resistensi kuman semakin bertambah sering dan banyak, termasuk terhadap antibiotika baru. Apabila resistensi terjadi terhadap antibiotika andalan, maka akan semakin sulit mengobati penyakit infeksi. Pemakaian pengobatan infeksi mata berat menggunakan obat empirik tanpa keuntungan data kultur dan tes kepekaan antibiotika, dapat dikatakan sebagai suatu kebohongan dengan risiko yang sebetulya tidak perlu. Walaupun obat empirik efektif, efek samping obat bisa terjadi, yang seharusnya dapat dihindari dibandingkan kalau ada pilihan antibiotika definitif yang kurang/tidak toksik, misalnya terhadap kerusakan epitel kornea pada kasus keratitis/ulkus kornea ataupun toksisitas sel retina pada kasus endoftalmitis. ${ }^{15}$

Pemakaian antibiotika saat ini tidak cukup dengan pemakaian antibiotika secara rasional tetapi seharusnya dengan pemakaian antibiotika secara bijaksana (prudent antibiotics use), yaitu suatu kegiatan terintegrasi untuk memaksimalkan efek antibiotika dan meminimalkan seleksi kuman resisten. Dasar prinsip pemakaian antibiotika secara bijak terdiri dari (1) pemilihan antibiotika yang tepat, meliputi diagnosis klinik yang tepat, mengetahui pola sensitifitas, mengetahui efektifitas berdasar hasil uji klinik, perkiraan sensitifitas terhadap kuman penyebab, farmakokinetik obat, status immunokompeten, spektrum kerja yang cukup (bukan broad spectrum), dan kombinasi antibiotika (2) penggunaan antibiotika yang benar, meliputi dosis obat, lama pengobatan, grup antibiotika, strategi pengobatan, dan peresepan obat - pemberian obat - pencatatan. Sebagai tambahan yang juga harus dikerjakan secara bersama meliputi surveilans pola sensitifitas antibiotika, monitoring pemakaian antibiotika, tindakan alternatif dari pemberian antibiotika dan program pengendalianinfeksi yang terintegrasi. Harus selalu ditekankan bahwa pencegahan lebih baik dari pada pengobatan. ${ }^{16,17}$

\section{DAFTAR PUSTAKA}

1. WHO. Nausheen S, Hammad R, Khan A. J Pak Med Assoc. Vol. 63, No.1, January 2013: 60-64.

2. Hopkins G and Pearson R. Drugs for the treatment of infections, in: Ophthalmic Drugs. Diagnostic and Theurapeutic Uses. Butterworth Heinemann Elsevier. Fifth ed.China;2007:179-201.

3. Szliter-Berger EA, Hazlett LD. Corneal Epithelium: Response to Infection. In: Dartt DA, Dana R, D'amore P, Niederkorn JY. Immunology, Inflammation and Diseases of The Eye. San Diego: Elsevier. Academic Press; 2011.p.79-85.

4. Thanathanee O, O'Brien TP. Corneal Microbiology. In: Copeland RA, Afshari NA. Copeland and Afshari's Principle and Practice of Cornea. New Delhi:Jaypee Brothers Medical Publishers (P) Ltd;2013.p.195-213.

5. Winarto. Keratomycosis. Simposium Mycosis. Kongres dan Temu Ilmiah Nasional III Perhimpunan Mikologi Kedokteran Indonesia (PMKI), Semarang, 2 Oktober 2004. 
6. Summaiya AM, Neeta DK, Sangita BR. Ocular Infections: Rational Approach to Antibiotic Therapy. National Journal Of Medical Research. Volume 2(1) Jan March 2012;22-24.

7. Winarto.Gambaran klinik dan mikrobiologik ulkus kornea di RSDK Semarang tahun 1988. Majalah Kedokteran Diponegoro.1990;4:247-53.

8. Snyder RW, Glasser DB: Antibiotic therapy for ocular infection. West J Med 1994; 161:579-584

9. Winarto. Managemen Ulkus Kornea Bakterial. Temu Ilmiah Penanganan Ulkus Kornea Secara Optimal. Kerjasama PERDAMI Jawa Tengah - Bag Mata FK UNDIP, Semarang, 15 September 2001.

10. Hopkins $G$ and Pearson R. Indication and contraindications for ophthalmic drugs, in: Ophthalmic Drugs. Diagnostic and Theurapeutic Uses. Butterworth Heinemann Elsevier. Fifth ed.China;2007:257-277.

11. McCulley et al. Fourth-generation fluoroquinolone penetration into the aqueous humor in humans.Ophthalmology. 2006; 113(6):955-9

12. Winarto. Pola kepekaan kuman penyebab ulkus kornea terhadap 12 macam antibiotika. Ophthalmologica Indonesiana $1997 ; 17(1): 5-8$
13. Winarto, Purnomo Hadi. Perbaikan kultur menggunakan media penyubur pada ulkus kornea, MKD vo 131 no. $1 \& 2$, 1996 : 45-50.

14. Winarto. Managemen Ulkus Kornea Bakterial. Temu Ilmiah Penanganan Ulkus Kornea Secara Optimal. Kerjasama PERDAMI Jawa Tengah - Bag Mata FK UNDIP, Semarang, 15 September 2001.

15. John P. Whitcher, Ocular Infections-A Rational Approach to Antibiotic Therapy. WJM, December 1994-Vol 161, No. 6:615-617.

16. Federation of Veterinarians of Europe. Antibiotics Resistance \& Prudent use of Antibiotics in Veterinary Medicine.

17. Ungemach FR, Muller-Bahrdt D, Abraham G. Guidelines for prudent use of antimicrobials and their implications on antibiotic usage in veterinary medicine. International Journal of Medical MicrobiologyVolume 296, Supplement 2, 23 June 2006:33-38 